Conclusions: The association between geographical area and cervical cancer persists after controlling for 10 other factors. The results are consistent with a multiple infectious aetiology of cervical cancer and suggest that there may be additional risk factors associated with geographical characteristics.

We thank Drs D M Parkin, N E Day and J Esteve for their many helpful discussions on this project when Dr. Zhang worked at International Agency on Cancer. This work was supported in part by a Cancer Research Grant from the Chinese Scientific Committee, a Research Fellowship by the International Agency for Research on Cancer, grants no CA 11535 from the National Cancer Institute, and no R01 ES 06718 from the national institute of Environmental Health Sciences, PHHS

1 Parkin DM, Laara E, Muir CS. Estimates of the worldwide frequency of sixteen major cancers in 1980 . Int $\mathcal{f}$ Cancer 1988;41:184-97.

2 Zhang ZF, Parkin DM, Yu SZ, Esteve J, Yang XZ. Risk factors for cancer of the cervix in a rural population in China. Int 7 Cancer 1989;43:762-7.

3 Zhang ZF, Graham S, Yu SZ, et al. Trichomonas vaginalis and cervical cancer: A prospective study. Ann Epidemio 1995;5:325-332.

4 Kleinbaum DG, Kupper LL, Morgenstern H. Epidemiologic research: principles and quantitative methods. New York: Van Nostrand Reinhold, 1982

5 Cox DR. Regression modles and life tables (with discussion). F $R$ Stat Soc B 1972;34:187-220.
ICRF GPRG,

Department of Public

Health and Primary

Care,

University of Oxford,

Gibson Building,

Radcliffe Infirmary,

Oxford OX2 6HE

$S$ Ziebland

A Fuller

J Muir

\section{Health Promotion}

Sciences Unit, London

School of Hygiene and

Tropical Medicine,

London

M Thorogood

Correspondence to:

Ms S Ziebland.

Accepted for publication

August 1995

$(\mathcal{F}$ Epidemiol Community Health 1996;50:105-106)

\title{
Desire for the body normal: body image and discrepancies between self reported and measured height and weight in a British population
}

\author{
Sue Ziebland, Margaret Thorogood, Alice Fuller, John Muir
}

In surveys of self reported height and weight a systematic bias towards declaring more inches and fewer pounds than is confirmed by subsequent objective measurement has been noted. ${ }^{12}$ A recent analysis of 11284 participants in the North American national health and nutrition examination survey found that weight and height were reported with only small errors on average, but misclassification was significant within important subgroups. Heavier people under reported their weight and exaggerated their height more than lighter people. It was concluded that these systematic discrepancies were consistent with American cultural ideals. ${ }^{3}$ Data are therefore presented to examine the possibility that these biases may be found in a British population.

During the OXCHECK trial of nurse health checks in general practice, a health and lifestyle questionnaire was completed at the study outset. A health check was subsequently performed and the information from these enables the comparison of self reported height and weight, and also body image, with objective meas-

Table 1 Discrepancies in reported height (in) by measured body mass index

\begin{tabular}{|c|c|c|c|c|c|c|c|c|}
\hline & $B M I<20$ & $(95 \% C I)$ & BMI $20-24$ & $(95 \% C I)$ & $B M I 25-29$ & $(95 \% C I)$ & $B M I>30$ & $(95 \% C I)$ \\
\hline \multicolumn{9}{|l|}{ Men } \\
\hline No & 13 & & 392 & & 424 & & 86 & \\
\hline $\begin{array}{l}\text { All } \\
\text { Age group: }\end{array}$ & 0.23 & NS & 0.35 & $(0 \cdot 24,0 \cdot 46)$ & 0.38 & $(0 \cdot 28,0 \cdot 48)$ & $0 \cdot 62$ & $(0 \cdot 41,0 \cdot 81)$ \\
\hline $\begin{array}{c}35-44 \\
45-54 \\
55-65\end{array}$ & $\begin{array}{l}0.40 \\
0.33 \\
0.50\end{array}$ & $\begin{array}{l}\text { NS } \\
\text { NS } \\
\text { NS }\end{array}$ & $\begin{array}{l}0 \cdot 31 \\
0 \cdot 32 \\
0 \cdot 47\end{array}$ & $\begin{array}{l}(0 \cdot 15,0 \cdot 47) \\
(0 \cdot 12,0 \cdot 51) \\
(0 \cdot 26,0 \cdot 69)\end{array}$ & $\begin{array}{l}0 \cdot 27 \\
0 \cdot 37 \\
0 \cdot 49\end{array}$ & $\begin{array}{l}(0 \cdot 08,0 \cdot 47) \\
(0.22,0 \cdot 52) \\
(0 \cdot 28,0 \cdot 70)\end{array}$ & $\begin{array}{l}0.54 \\
0.60 \\
0.47\end{array}$ & $\begin{array}{l}(0 \cdot 17,0 \cdot 92) \\
(0 \cdot 22,0 \cdot 98) \\
(0 \cdot 27,1 \cdot 06)\end{array}$ \\
\hline \multicolumn{9}{|l|}{ Women } \\
\hline $\begin{array}{l}\text { No } \\
\text { All } \\
\text { Age group }\end{array}$ & $\begin{array}{l}61 \\
0 \cdot 15\end{array}$ & NS & $\begin{array}{l}542 \\
0 \cdot 37\end{array}$ & $(0 \cdot 20,0 \cdot 46)$ & $\begin{array}{r}370 \\
0.44\end{array}$ & $(0 \cdot 34,0 \cdot 56)$ & $\begin{array}{l}181 \\
0.64\end{array}$ & $(0 \cdot 48,0 \cdot 79)$ \\
\hline $\begin{array}{l}35-44 \\
45-54 \\
55-64 \\
\end{array}$ & $\begin{array}{r}0.13 \\
-0.25 \\
0.46 \\
\end{array}$ & $\begin{array}{l}\text { NS } \\
\text { NS } \\
\text { NS }\end{array}$ & $\begin{array}{l}0 \cdot 18 \\
0 \cdot 27 \\
0 \cdot 87\end{array}$ & $\begin{array}{l}(0.03,0.33) \\
(0.11,0.42) \\
(0.69,1.04)\end{array}$ & $\begin{array}{l}0.21 \\
0.41 \\
0.68\end{array}$ & $\begin{array}{l}(0 \cdot 16,0 \cdot 26) \\
(0.26,0.56) \\
(0.45,0.92)\end{array}$ & $\begin{array}{l}0 \cdot 40 \\
0 \cdot 30 \\
1 \cdot 13\end{array}$ & $\begin{array}{l}(0 \cdot 13,0 \cdot 66) \\
(0 \cdot 11,0 \cdot 50) \\
(0 \cdot 86,1 \cdot 41)\end{array}$ \\
\hline
\end{tabular}

Table 2 Discrepancies in weight (lb) by measured body mass index

\begin{tabular}{|c|c|c|c|c|c|c|c|c|}
\hline & $B M I<20$ & $(95 \% C I)$ & BMI 20-24 & $(95 \% C I)$ & BMI 25-29 & $(95 \% C I)$ & $B M I>30$ & $95 \% C I$ \\
\hline \multicolumn{9}{|l|}{ Men } \\
\hline $\begin{array}{l}\text { No } \\
\text { All }\end{array}$ & 3 & & 378 & & 435 & & 58 & \\
\hline $\begin{array}{l}\text { All } \\
\text { Age group: }\end{array}$ & $5 \cdot 67$ & NS & $-0 \cdot 31$ & NS & $-2 \cdot 72$ & $(-3 \cdot 43,-1 \cdot 99)$ & $-6 \cdot 98$ & $(-9 \cdot 56,-4 \cdot 40)$ \\
\hline $\begin{array}{l}35-44 \\
45-54 \\
55-64\end{array}$ & $\begin{array}{l}(1) \\
(1) \\
(1)\end{array}$ & $\begin{array}{l}\text { NS } \\
\text { NS } \\
\text { NS }\end{array}$ & $\begin{array}{r}-1.60 \\
-0.33 \\
1.69\end{array}$ & $\begin{array}{l}(-2 \cdot 56,-0 \cdot 64) \\
\text { NS } \\
(0 \cdot 22,3 \cdot 15)\end{array}$ & $\begin{array}{l}-4 \cdot 44 \\
-1.88 \\
-1.95\end{array}$ & $\begin{array}{l}(-5.61,-3.27) \\
(-3.08,-0.69) \\
(-0.55,-0.36)\end{array}$ & $\begin{array}{r}-10 \cdot 26 \\
-5 \cdot 59 \\
-5 \cdot 23\end{array}$ & $\begin{array}{l}(-16 \cdot 6,-4 \cdot 54) \\
(-10 \cdot 7,-0 \cdot 50) \\
(-8 \cdot 39,-2 \cdot 07)\end{array}$ \\
\hline \multicolumn{9}{|l|}{ Women } \\
\hline $\begin{array}{l}\text { No } \\
\text { All } \\
\text { Age group: }\end{array}$ & $\begin{array}{l}41 \\
1.66\end{array}$ & NS & $\begin{array}{l}534 \\
-1 \cdot 07\end{array}$ & $(-1 \cdot 60,-0.53)$ & $\begin{array}{l}385 \\
-4.04\end{array}$ & $(-4 \cdot 88,-3 \cdot 20)$ & $\begin{array}{l}131 \\
-7 \cdot 34\end{array}$ & $(-9 \cdot 22,-5 \cdot 46)$ \\
\hline $\begin{array}{l}35-44 \\
45-54 \\
55-64\end{array}$ & $\begin{array}{l}0 \cdot 90 \\
2 \cdot 00 \\
5 \cdot 60\end{array}$ & $\begin{array}{l}\text { NS } \\
\text { NS } \\
\text { NS }\end{array}$ & $\begin{array}{r}-1.76 \\
-0.97 \\
0.13\end{array}$ & $\begin{array}{l}(-0.95,-2 \cdot 56) \\
(-0 \cdot 10,-1 \cdot 84) \\
\text { NS }\end{array}$ & $\begin{array}{l}-5 \cdot 73 \\
-3.95 \\
-2.68\end{array}$ & $\begin{array}{l}(-7.43,-4.03) \\
(-5.37,-2.53) \\
(-3.92,-1.44)\end{array}$ & $\begin{array}{r}-10.38 \\
-7 \cdot 28 \\
-5 \cdot 66\end{array}$ & $\begin{array}{l}(-13 \cdot 8,-6 \cdot 96) \\
(-10 \cdot 4,-4 \cdot 22) \\
(-8 \cdot 76,-2 \cdot 56)\end{array}$ \\
\hline
\end{tabular}

Note: measures above the 95 th and below the 5 th percentile have been excluded. 
Table 3 Body image by measured body mass index and gender

\begin{tabular}{|c|c|c|c|c|c|c|c|c|}
\hline \multirow[t]{2}{*}{ Image } & \multicolumn{4}{|l|}{ Men } & \multicolumn{4}{|l|}{ Women } \\
\hline & $B M I<20$ & BMI 20-24 & $B M I 25-29$ & $B M I>30$ & $B M I<20$ & BMI 20-24 & $B M I 25-29$ & $B M I>30$ \\
\hline $\begin{array}{l}\text { No } \\
\text { Too light }(\%) \\
\text { About right }(\%) \\
\text { Too heavy }(\%) \\
\text { Don't know (\%) }\end{array}$ & $\begin{array}{l}3 \\
(2) \\
(1)\end{array}$ & $\begin{array}{r}366 \\
6 \\
76 \\
12 \\
6\end{array}$ & $\begin{array}{r}409 \\
-\quad \\
27 \\
68 \\
5\end{array}$ & $\begin{array}{l}51 \\
- \\
(2) \\
96 \\
-\end{array}$ & $\begin{array}{l}35 \\
26 \\
67 \\
(1) \\
(1)\end{array}$ & $\begin{array}{r}517 \\
2 \\
57 \\
37 \\
4\end{array}$ & $\begin{array}{r}369 \\
-\quad \\
10 \\
84 \\
6\end{array}$ & $\begin{array}{l}124 \\
- \\
- \\
96 \\
4\end{array}$ \\
\hline
\end{tabular}

urements. The questionnaire was sent to men and women aged 35 to 64 during $1989(80 \cdot 3 \%$ response rate). The analysis was based on the $2205(66 \%$ of those who were initially sent a questionnaire) who subsequently took up a health check offer during 1989-90. The OXCHECK method has been previously published. ${ }^{4}$

As measured body mass index increased, so did overestimates of height and underestimates of weight (see tables 1-3). The greatest discrepancy is evident for both men and women with a body mass index over 30 . The few respondents ( 3 men and 41 women) with a body mass index under 20 over reported their weight. The oldest age groups for obese men and women had the biggest mean difference between self reported and measured height. It was, however, the younger obese and overweight men and women who had the greatest disparity between self reported and measured weight.

Respondents were asked if they thought they were the right weight for their height, too light, or too heavy. Of those with a body mass index between 20 and 25 ("normal"), $76 \%$ of men compared with $57 \%$ of women thought that they were about the right weight. Amongst those with a body mass index between 25 and 29 ("overweight") $27 \%$ of men but only $10 \%$ of women considered their weight "about right".

Discussion: In this sample the gap between self reported and measured height was small and there was no apparent difference between men and women. Adults may be measured rarely and much of the observed discrepancy may be due to simple error, based on measurements performed long ago. Some respondents may be reporting their preferred, rather than actual weight. Women in the "over- weight" group under report their weight more than men, which may reflect a body image preference for brawny, muscled male bodies and svelte women.

The data reported here are only for those respondents who both completed a health and lifestyle questionnaire and attended a health check. It is possible that these respondents may be more willing, or more able, to provide accurate assessments of their height and weight. The disparity between reported and measured height and weight in this sample may, therefore, be an underestimate of that in the general population.

In $1992,42 \%$ of men and $29 \%$ of women were classified as overweight and $12 \%$ of men and $15 \%$ of women as obese (Office of Population Censuses and Surveys, 1994). The data reported here suggest that overweight men are more satisfied with their bodyshape than overweight women. It may be that what is categorised as a male (BMI) in the overweight range is considered acceptable or even desirable by men. This may explain the apparent anomaly of the higher prevalence of overweight among men and obesity among women. Excess body weight has been highlighted as an increasing problem and researchers using self reported measures need to be aware that under reporting of weight and over reporting of height is positively associated with body mass index.

1 Gupta MA, Schork NJ, Dhaliwal JS. Stature, drive for thinness and body dissatisfaction: a study of males and females from a non-clinical sample. Can f Psychiatry 1993;38: $59-61$

2 Alverez-Torices JC, Franch-Nadal J, Alvarez-Guisasola F, Hernandez-Majia R, Cueto-Espinar A. Self reported height and weight and prevalence of obesity. Study in a Spanish Population. International fournal of Obesity and Related Metabolic disorders 1993;17(11):663-7.

3 Rowland M. Self reported weight and height. Am $f$ Clin Nutr 1990;52:1125-33.

4 Thorogood M, Coulter A, Jones L, Yudkin P, Muir J, Mant D. Factors affecting response to an invitation to attend for a health check. $\mathcal{F}$ Epidemiol Community Health 1993;47: 224-8. 